\title{
UNIVERSITY OF PENNSYLVANIA RADIOCARBON DATES XV
}

\section{BARBARA LAWN}

\author{
Department of Physics and University Museum \\ University of Pennsylvania, \\ Philadelphia, Pennsylvania 19104

\section{INTRODUCTION}

This clate list includes most of the archaeologic and geologic samples dated in this laboratory since publication of our last date list (R., v. 12 , p. 577-589), as well as some samples which had previously been dated, but lacked the sample information necessary for publication. Known-age samples, completed in this time period, will be reported elsewhere. The B.P. ages are based upon A.D. 1950, and have been calculated with the half-life value of $5568 \mathrm{yr}$. All samples were counted at least twice for periods of not less than 1000 minutes each. Errors quoted for each sample are clerived from the measurement of the sample, the background, and of several counts of our mid-19th century standard oak sample, but do not include the half-life crror. All samples were pretreated with $3 \mathrm{~N} \mathrm{HCl}$, and some, where noted, were given additional pretreatment with $2 \% \mathrm{NaOH}$ for the removal of possible humic acid contaminants.

Our mid-19th century calibration samples have an average age of $126 \mathrm{yr}$. When corrected for this age, they have $\mathrm{C}^{1+1}$ contents equal to $95 \%$ of the NBS oxalic acid standard. The average $C^{1.3}$ relationship between the oak standards and the NBS limestone standard \#20 is $-25.7 \pm 1.3 \%$ as measured on the University of Pennsylvania mass spectrograph. Where $\delta \mathrm{C}^{13}$ is reported and the results accordingly corrected for isotopic fractionation, the $C^{1 / 3}$ relationship has been measured with respect to the oak standard.

The MASCA corrected dates, appearing in the sample comments, have been arrived at by applying appropriate correction factors to dates calculated with the 5790 half-life. 'The MASCA correction factors are based on the $C^{1: 1}$ dating of almost 200 tree-ring dated sequoias and bristlecone pines. In this date list the corrections used are those published by Ralph (1971, p. 1-48). It is anticipated that these correction factors will become more precise as more tree-ring dated samples are processed. It is hoped that composite plots of calibration curves and lists of correction factors, based upon the work of the laboratories of Univ. of Arizona (Damon et al., 1970, p. 615-618), Univ. of California, Sin Diego, La Jolla (Seuss, 1970, p. 303-911) and Univ. of Pennsylvania (Ralph and Michael, 1970 , p. 619-623)-more than 500 dates in all-will be agreed upon in the future.

I wish to thank John Hedrick and Ray Costa for their careful work in the processing of these samples. 


\section{SAMPLE DESCRIPTIONS}

I. ARCIIAEOLOGIC SAMPLES

\section{A. Mediterranean}

1. Italy

\section{Cosa series}

Samples from larbor area at Cosa, Ansedonia, Italy $\left(12^{\circ} 24^{\prime} \mathrm{N}\right.$ Lat, $11^{\circ} 17^{\prime}$ E Long). Coll. and subm. 1969 by J. D. Lewis and A. M. McCann, Am. Acad. in Rome, Italy (Brown, 1951).

\section{P-1594. COH-69-W 1}

$303 \pm 36$

Wood from rib of ship's hull resting in shallow rock shore along coast of Ansedonia, within confines of harbor. Comment: MASCA corrected date $=$ A.D. 1588 .

\section{P-1722. PC-69-W22a}

$$
2020 \pm 44
$$

$70 \mathrm{B.c}$.

Wood from cofferdam of Roman dock in situ, buried under Im earth and mud at $\mathrm{W}$ end of Lago di Burano, a narrow lagoon running parallel to the sea just behind the sand dunes. The $W$ end is believed to be location of an inner harbor connected by a ship-canal to the sea and protected at the seaward end by a large stone and masomry constructed breakwater. For another date for this cofferdam, see I-3968, $1925 \pm 85$ (R., 1970, v. 12, p. 122). Comment: MASCA corrected date =70 B.C.

\section{P-1723. Roman Forum, Italy}

$2462 \pm 71$ 512 B.C.

Carbonized wood and perhaps thatch from debris of burnt hut or huts, buried in pit, sealed across top by thin layer of clay in Area (2), Stratum VI pit of the Regia in the Roman Forum, Rome, Italy ( $41^{\circ} 54^{\prime}$ $\mathrm{N}$ Lat, $12^{\circ} 27^{\prime} \mathrm{E}$ Long). Coll. 1969 and subm. by F. E. Brown, Am. Acad. in Rome, Italy. Comment: MASCA corrected date $=636$ B.c.

\section{P.1756. Populonia, Italy}

$2588 \pm 47$

638 B.C.

Wood, U-16, from underwater, harbor area at Populonia, Italy $\left(43^{\circ}\right.$ $00^{\prime} 00^{\prime \prime} \mathrm{N}$ Lat, $1^{\circ} 52^{\prime} 30^{\prime \prime} \mathrm{E}$ Long). Coll. July 1970 and subm. by A. M. McCann, Univ. California at Berkeley. Sample from plank buried in sand, ca. $0.3 \mathrm{~m}$ under present surface, found ca. $100 \mathrm{~m} \mathrm{~N}$ of $\mathrm{N}$ end of modern W jetty of harbor in ca. $13.5 \mathrm{~m}$ water. Harbor area of Populonia has been dredged in modern times and large gouges in sea floor occur, for depth of up to $1.8 \mathrm{~m}$. Sample, and ancient pottery of 5 th century B.c. and later, were found surrounded by weeds in one of these pockets. Comment: MASCA corrected date $=816$ B.C.

\section{Straits of Messina series}

Wood, Pinus (halepensis), id. by B. F. Kukachka, Forest Prods. Lab., U.S. Dept. Agric., Maclison, Wisconsin, from shipwreck in Straits of 
Messina, Italy ( $38^{\circ} 14^{\prime} \mathrm{N}$ I at, $15^{\circ} 39^{\prime} \mathrm{E}$ Long). Samples from depth $35 \mathrm{~m}$ in sandy area of sea-bottom, partly resting on bedrock. Estimated date of shipwreck: ca. 300 в.c. Samples coll. and subm. by D. I. Owens, Univ. Mus., Univ. Pennsylvania, Philadelphia.

\section{P-1728. Straits of Messina}

$$
1541 \pm 40
$$

Two smaller pieces of wood (less riddled by shipworms) of 3 subm. 1970, from ship's timbers. Comment: MASCA corrected date $=$ A.D. 333 (D.I.O.) wood of sample could well have come from another ancient shipwreck in immediate vicinity and swept into area by swift currents in Straits. Close proximity of ancient shipwrecks of different periods, sometimes overlapping one another, is now well documented by Univ. Mus. excavations led by G. F. Bass, Yassi Ada, Turkey (P-1395, R., 1970, v. 12 , p. 581 ).

\section{P-1755. Straits of Messina}

Outer sec. of remaining larger piece of wood from ship's imbers. subm. 1970. Comment: MASCA corrected clate $=531$ в.c.

\section{P.1814. Straits of Messina}

Object \#7, piecc of ship's timbers, subm. 1971. Comment: MASCA corrected date $=446$ в.c.

\section{Greece}

\section{Sesklo series}

Sesklo is a high prehistoric mound (acropolis), $8 \mathrm{~km} \mathrm{~W}$ of Volos, capital of Thessaly, Greece ( $39^{\circ} 23^{\prime} \mathrm{N}$ Lat, $22^{\circ} 49^{\prime} \mathrm{E}$ Long). New excavations of Aichaeol. Soc. Athens dir. by D. R. Theocharis, Ephor of Antiquities for Thessaly. Samples coll. 1968, 1968 and subm. by D. R. Theo charis, Archaeol. Mus., Volos, Greece.

\section{P-1671. S.68.37, Late Neolithic}

Very fine clark soil, Sample S.68.37, from Sq. E 3, Late Neolithic (Dimini period). Comment: MASGA corrected date $=4372$ в.C.

\section{P-1672. S.68.79, Middle Neolithic}

$6504 \pm 85$ phase).

Fine dark soil, Sample S.68.79, from Rm. 12, Middle Neolithic (later

\section{P.1674. S.68.132, Middle Neolithic}

$6964 \pm 92$

Charcoal, Sample S.68.132, from wooden column, Middle Neolithic.

\section{P.1675. S.68.156, Middle Neolithic}

$6694 \pm 87$

Charcoal, Sample S.68.156, from wooden column, Middle Neolithic. 
P.1676. S.68.126, Middle Neolithic Floor

Fine dark soil containing rootlets, Sample S.68.126, Midldle Neolithic Floor. Comment: as many rootlets as possible removed by hand.

P-1677. S.68.36, Middle Neolithic

$6741 \pm 103$

Charcoal, Sample S.68.36, from House 50, deep sounding, Middle Neolithic. Comment: undersized sample, $95 \%$.

P-1678. S.68.98, Earliest Pottery Neolithic $7427 \pm 78$ 5477 в.c.

Charcoal and fine dark soil, Sample S.68.98, from Trench 63, W, Earliest Pottery Neolithic.

P-1679. S.63.122, Earliest Pottery Neolithic

$7611 \pm 83$

Charcoal and fine dark soil, Sample S.63.122, from depth $3.88 \mathrm{~m}$, Earliest Pottery Neolithic.

P-1680. S.63.124A, Pre-Pottery Neolithic

Charcoal and soil, Sample S.63.124. , from Sq. B 1, depth 4.10 to $4.20 \mathrm{~m}$, Pre-Pottery Neolithic.

\section{P.1681. S.63.124B, Pre-Pottery Neolithic}

$7755 \pm 97$

Charcoal and soil, Sample S.69.124B, from Sq. 1 to $\Delta 1$, Pre-Pottery Neolithic.

\section{P-1682. S.63.121, Pre-Pottery Neolithic}

$7483 \pm 72$

Charcoal and soil, Sample S.63.121, from Sq. B, depth 4.32m, PrePottery Neolithic.

General Comment: this series, with exception of $\mathbf{P}-1671$, is beyond range of MASCA correction factors now avilable (May, 1972).

\section{B. Near East}

\section{Iraq}

\section{P-1466. Khafajah, Sin Temple I}

Khafajal is a large mound complex on E bank of Diyala R., $16 \mathrm{~km}$ $\mathrm{NE}$ of junction with Tigris in Iraq $\left(33^{\circ} 20^{\prime} \mathrm{N}\right.$ Lat, $44^{\circ} 3^{\prime} \mathrm{E}$ Long). The Sin Temple was excavated to its deepest level, dated by its excavators as Protoliterate C. Sample consisted of dark brown soil containing rootlets, from base of wall stubs still standing on $\mathbf{N}$ edge of pit excavated 1937-38 to ground-water level (now silted in with flood deposits). Alt. and position indicate Sin I walls (Delougaz and Lloyd, 1942, Fig. 3, Wall d). Excavators could expose only a very small area and established plan by tunnelling. Sample coll. 1955 and subm. 1968 by F. R. Matson, Pennsylvania State Univ., Univ. Park, Pennsylvania. Comments: $\mathrm{NaOH}$ pre- 
treatment. MASCA corrected date $=4963$ в.c. Comment by Matson based on uncorrected date calculated with 5730 half-life. (F.R.M.): date is almost a millennium early for Protoliterate C: Contamination from possible inclusion of bitumen and from frequent flooding of pit by Diyala $R$. since excavation must be consiclered. Cif. P-530, $4672 \pm 74$ (R., 1963, v. 5, p. 85$)$.

\section{P-1468. Gasur (Nuzi)}

$4002 \pm 61$

Casur, the Akkadian city found beneath the Hurrian city of Nuzi, $17.7 \mathrm{~km}$ SW of Kirkuk, Iraq (35 $22^{\prime} \mathrm{N}$ Lat, $44^{\circ} 15^{\prime} \mathrm{E}$ Long). Sample coll. 1955 from $S$ wall of Pit L-4 from a clark soil band 10 to $12 \mathrm{~cm}$ thick, $1.7 \mathrm{~m}$ below base of a libn structure that could be traced in pit walls, and probably from above Pavement V (Starr, 1939, I, p. 21, II, plan no. 5) and subm. 1968 by F. R. Matson, Pennsylvania State Univ., Univ. Park, Pennsylvania. Comments: NaOH pretreatment. MASCA corrected date $=2673$ B.c. Comment by Matson based on uncorrected date calculated with 5730 hall-life. (F.R.M.): date is quite satisfactory for Akkadian period of occupation of Casur, which has been surmised from study of clay tablets with Akkadian texts found on Pavements $V$ and IV.

\section{Tepe Gawra series}

Tepe Gawra is a large mound ca. $32 \mathrm{~km}$ NNE of Mosul, Iraq $\left(36^{\circ}\right.$ $33^{\prime} \mathrm{N}$ Lat, $43^{\circ} 15^{\prime} \mathrm{E}$ Long). It was excavated by Univ. Mus., Univ. Pemnsylvania, 1931 to 1938 under direction of E. A. Speiser, and in some seasons under Charles Bache. Level XIX was the carliest excavated over an extended area. Level XX, which was tested, was of the Halaf period. Level XIX-XVII, in terms of pottery, represcnt early phase of $\mathrm{N}$ Ubaid period; levels XIIA-XII are terminal N Ubaid (Tobler, 1950, p. 4). Samples for P-1494-1496 (cf.) were from NW face of sounding in Sqs. 3-5, G-K, on either side of the "intrusive pit" (Tobler, 1950, pls. XVIII-XX, XIIII-XLV) after the face had been extensively cleaned. Samples coll. 1954 and subm. 1968 by F. R. Matson, Pennsylvania State Univ., Univ. Park, Pennsylvania.

\section{P-1497. Level XII}

$5787 \pm 72$ 3837 в.c.

Sample, mostly soil $(3 \%$ C) from a dark band in scarp face at $S$ corner of Rm. 81, $15 \mathrm{~cm}$ below Level XIA, the top of the scarp (Tobler, pls. VIII, XXVIIIb). Comment: NaOH pretreatment. MASCA corrected date $=4761$ i.c.

\section{P-1496. Level XVII}

Sample, mostly soil $(2.45 \%$ C) from top of cleaned face of strat. cut, just $\mathrm{E}$ of "intrusive pit," containing some rootlets. From debris between Levels XVII and XVI. Comment: NaOH pretreatment. MASCAA corrected date $=4971$ в.c. 
P-1495. Level XVIII

Sample, mostly soil, $(1.75 \%$ C) from ashy dark soil band, 43 to $63 \mathrm{~cm}$ above P-1494 (cf.). Comment: $\mathrm{NaOH}$ pretreatment.

P-1494. Level XIX

$7002 \pm 82$

5052 в.c.

Sample, mostly soil $(1.75 \%$ C) from dark soil band at exterior base W wall, Rm. 44, Level XIX (Tobler, 1950, pl. XX). Comment: $\mathrm{NaOH}$ pretreatment.

General Comments: P-1491 and -1495 are beyond range of MASCA correction factors now available (May, 1972). The following comment by Matson was based on uncorrected date calculated with the 5730 half-life. (F.R.M.): Samples P-1494-1497 show time range of N Ubaid period at Tepe Gawra-about a millennium. These 4 samples are internally consistent. Overlap between early Ubaid, Jater Halaf (cf. P-1487), and late Hassuna (cf. P-1499) strengthen the suggestion that Halaf is an intrusive culture in $\mathrm{N}$ Mesopotamia where Ubaid gradually succeeds HassunaSamarra in many village areas.

\section{P-1498. Tell Uqair}

$6599 \pm 107$

4649 B.c.

$\delta C^{13}=+38.9 \%$

Tell Uqair is a mound ca. $80.5 \mathrm{~km} \mathrm{~S}$ of Baghdad, midway between Tigris and Euphrates R. in Iraq (32० $57^{\prime} \mathrm{N}$ Lat, $44^{\circ} 38^{\prime} \mathrm{E}$ Long). At site was evidence of occupation ranging from an Ubaicl settlement into Early Dynastic times. Sample consisted of shells from excavation dump to NW of the deep Ubaid souncling. A few shells were included from NE dump. Faud Safar thought shells probably came from debris of House A, late in the Tell Uqair sequence. He had found a "heavy deposit of fresh water musscls" in House A (Lloyd and Safar, 1943, p. 149, pl. VIb). Sample coll. 1955 and subm. 1968 by F. R. Matson. Comments: sample undersized, $85.20 \%$. MASCA corrected date $=4927$ в.c. The following comment by Matson was based on uncorrected date calculated with the 5730 half-life. (F.R.M.): mass spectrometer corrected date is consistent with estimates of early Ubaid in S Mesopotamia. Compare P-1494, $7002 \pm 82$ (cf.) and H-138-123, $6070 \pm 160$ (Science, 1957, v. 126, p. 198).

\section{P-1499. Gird Ali Agha}

$6927 \pm 63$ 4977 B.c.

Gird Ali Agha is a small mound on left bank of Greater Zab R., Iraq ( $36^{\circ} 27^{\prime} \mathrm{N}$ Lat, $43^{\circ} 48^{\prime} \mathrm{E}$ Long) (Braidwood and Howe, 1960, p. 26). This Hassuna period site in NE Iraq helps link upper levels of Jarmo with Hassuna in a cultural sequence. Sample is hearth material of ash and charcoal $(2.65 \%$ C) from Operation I, Sec. B, Sq. 3, Feature 6 to 7 , under Floor 3. Coll. 1954 and subm. 1968 by F. R. Matson. Comments: $\mathrm{NaOH}$ pretreatment. Date is beyond range of MASCA correction factors 
now available (May, 1972). (F.R.M.): date falls at upper end of date range from Hassuna period sites. Cf. K-960, -972, -981 (R., 1968, v. 10 , p. 323), P-855, -857 (R., 1965, v. 7, p. 190), TK-23, -24 (R., 1969, v. 11 , p. 513), W-623 and -660 (R., v. 2, p. 183).

\section{Banahilk series}

Banahilk is a small Halaf period site in Kurdistan, $1.6 \mathrm{~km} \mathrm{SW}$ of village of Diyana, Iraq $\left(36^{\circ} 40^{\prime} \mathrm{N}\right.$ Lat, $44^{\circ} 45^{\prime} \mathrm{E}$ Long) tested in 1955 by P. J. Watson (Braidwood and Howe, 1960, p. 23, 33-35. Watson's site report in press). Site is at $\mathbf{E}$ edge of distribution of Halaf-style pottery villages. Samples coll. 1954 and subm. 1968 by F. R. Matson.

\section{P.1501. Trench D II}

$6309 \pm 78$

Black hearth material from top level of Halaf deposits, Trench D II, $1.8 \mathrm{~m}$ below surface.

\section{P.1502. Trench D I}

$6752 \pm 85$

Charcoal from hearth in 'Trench D I, Floor $6,2.2 \mathrm{~m}$ below surface, beneath Feature 1.

\section{P.1504. Trench D I}

$6854 \pm 72$

4904 B.c.

$\delta C^{13}=+7.3 \%$

Helix shells from same locus as P-1502. Comment: (F.R.M.): this mass spectrometer corrected clate agrees with charcoal date from same hearth (P-1502, $6752 \pm 85)$.

General Comments: this series is beyond range of MASCA correction factors now available (May, 1972). (F.R.M.): dates indicate time span for midclle Halaf period near its E periphery. See comments for P-1487 (cf.).

2. Syria

\section{P-1487. Tell Chagar Bazar}

$6665 \pm 77$

4715 B.c.

Sample, mostly soil or ash ( $2.1 \%$ C) from Tell Chagar Bazar, on Khabur R. near $\mathrm{N}$-central border of Syria $\left(36^{\circ} 51^{\prime} \mathrm{N}\right.$ Lat, $41^{\circ} 7^{\prime} \mathrm{L}$ Long). A "Prehistoric Pit" was dug to determine main period of occupation (Mallowan, 1936, p. 7). An ash level near base of still exposed, but weathered $S$ face of pit, $11.3 \mathrm{~m}$ bclow surface, was estimated to correspond to Levels 11-12, in which initial extensive appearance of Halaf ware at site was found. Sample coll. 1955 and subm. 1968 by F. R. Matson. Comments: NaOH pretreatment. Date is beyond range of MASCA correction factors now available (May, 1972). (F.R.M.): date falls well within estimates for Halaf Period. It is later than those obtained from Tell Halaf: GrN-2660, $7570 \pm 35$ (R., 1964, v. 6, p. 355) 
and Arpachiyah: P-584, $7027 \pm 83$; and P-585, $8064 \pm 78$ (R., 1965, v. 7 , p. 188). It is earlier than one Banahilk date (P-150l, (f.) from upper Halafian debris, but agrees well with 2 others from Banahilk (P-1502, -1504 , cf.). Dates confirm excavator's suggestion that Halaf "ware entered Chagar Bazar later than it entered the Nineveh region" (Mallowan, 1936, p. 10). A "very late- or post-Halafian" date $(6465 \pm 100$, Braidwood et al., 1971, p. 1240) from Groningen Lab. has recently been cited for Gerikihaciyan, a Halafian site excavated by Watson in SE Turkey. Two other samples are being processed.

\section{Turkey}

\section{P.1473. Tell Judaidah, Phase G}

$4782 \pm 60$ 2832 в.c.

Tell Judaidah is large mound in $A$ muq, Plain of Antioch, $1.5 \mathrm{~km} \mathrm{SE}$ of Rihaniyah, Turkey $\left(36^{\circ} 16^{\prime} \mathrm{N}\right.$ Lat, $36^{\circ} 35^{\prime} \mathrm{E}$ Long). Phase $\mathrm{G}$ is equated with Late Protoliterate-larly Dynastic period in Mesopotamia, with EB II in Palestine, and with Dynasty I of Egypt (Watson, I965, p. 75-77). Sample from ash level with bits of charcoal $(3.2 \%$ C) in Cut JK-3 at basal Phase G just below base of circular mud brick wall. Coll. 1955 and subm. 1968 by F. R. Matson (Braidwood and Braidwood, 1960). Comments: $\mathrm{NaOH}$ pretreatment. MASCiA corrected date $=3676$ B.c. Following comment based on uncorrected date calculated with 5730 half-life. (F.R.M.): date agrees very well with archaeol. established correlations.

\section{Iran}

\section{Dinkha Tepe series}

Dinkha Tepe $\left(36^{\circ} 59^{\prime} 51^{\prime \prime} \mathrm{N}\right.$ Lat, $45^{\circ} 10^{\prime} 41^{\prime \prime} \mathrm{E}$ Long) is in Ushnu Valley, W. Azerbaijan, Iran. Samples coll. 1968 by Hasanlu Project, jointly sponsored by Univ. Mus., Univ. of Pennsylvania, Metropolitan Mus. Art New York City, and Archaeol. Service Iran, subm. by excavation clirector, R. H. Dyson, Jr., Univ. Mus., Univ. Pennsylvania, Philadelphia, Pennsylvania. Remains of 4 major occupations have been uncovered: Dinkha I (Islamic); Dinkha If (Iron Age II equal to Hasanlu IV, ca. 1000 to 800 в.c.); Dinkha III (Iron Age I equal to Hasanlu V, ca. 1350 to 1000 B.C. and Dinkha IV (Bronze age equal in part to Hasanlu VI, ca. ?1900 to ?1350 в.c.). Chronology based on earlier radiocarbon dates for Hasanlu and studies of relative chronology (Dyson, 1965; Ralph, 1959; Stuckenrath, 1963; Stuckenrath et al., 1966).

\section{Dinkha IV}

P-1690. Di-68-S.7, B9/10a

Charcoal from Op. B9/10a, St. 2A, Area 5 (Field Sample \# 3), N edge of central Mound. Comment: MASCA corrected date $=1895$ в.c. 


\section{P.1692. Di-68-S.11AI, B9/10a}

$3576 \pm 70$ $1626 \mathrm{B.C}$.

Charcoal from Op. B9/10a, St. 7 (Field Sample \#14) at level of Wall $\mathrm{K}$ and hearth of Area $11, \mathrm{~N}$ edge of central mound. Comment: MASCA corrected date $=1933$ B.c.

\section{P-1720. Di-68-S.9, B9/10a}

$3395 \pm 68$ edge of central mound. Comment: MASCA corrected date $=1747$ B.C.

P-1721. Di-68-S.11A and 11BII, B9/10a

$3458 \pm 66$

Two samples of charcoal from Op. B9/I0a, St. 7, Di-68-S.11A (Field Sample \#15) in SW corner of Wall K and Di-68-S.11BII (Field Sample \#13) at level of Wall $\mathrm{K}$ and Hearth $11, \mathrm{~N}$ edge of central mound. Com$m e n t: \mathrm{NaOH}$ pretreatment. MASCA corrected date $=1812$ B.c. (R.H.D.): these 2 combincd samples represent deepest stratified carbon above virgin soil at site.

\section{P-1693. Di-68-S.5A and B, G10h}

Charcoal and soil, Op, GIOh, St. $50 \mathrm{~cm}$, from single black lens $50 \mathrm{~cm}$ below and sealed by Wall $\mathrm{O}, \mathrm{E}$ edge of central mound. Comment: $\mathrm{NaOH}$ pretrcatment. MASCA corrected date $=1704$ в.c.

General Comment: for additional dates from Dinkha IV, see P-1231, -1232 , - $1450,-1452,-1239,-1430,-1552$, and $-1429 / 31$ (R., 1970, v. 12, p. 578-579).

$$
\text { C. Africa }
$$

\section{Cameroon}

\section{Pouss series}

Pouss is Iron age mound in Logone Valley, N Cameroon $\left(10^{\circ} 51^{\prime}\right.$ N Lat, 15 4' E Long). Samples coll. 1969 by Frank Bartell; subm. by N. C. David, Univ. Mus., Univ. Pennsylvania, Philadelphia, Pennsylvania.

\section{P-1765. Stratigraphic Units 1 and 2}

$$
199 \pm 43
$$

Charcoal containing rootlets from strat. Units 1 and 2. Comment: rootlets removed by hand. $\mathrm{NaOH}$ pretreatment. MASCA corrected date $=$ A.D. 1638 .

\section{P-1766. Strat. Units 3 and 4}

$$
550 \pm 29
$$

Charcoal containing many rootlets from strat. Units 3 and 4 . Comment: rootlet pretreatment (Haynes, 1966; Lowdon et al., 1970, p. 474). MASCA corrected date $=$ A.D. 1383. 
P-1773. Strat. Units 3 and 4

A.D. 1343

$607 \pm 49$

Portion of same sample as P-I766. Comment: rootlets removed by hand and sample given regular $\mathrm{HCl}$ and $\mathrm{NaOH}$ pretreatment. MASCA corrected date $=$ A.D. 1324 .

\section{P-1767. Strat. Units 15 and 16}

$889 \pm 35$

Charcoal and soil containing rootlets from strat. Units 15 and 16 . Comment: rootlets removed by hand. $\mathrm{NaOH}$ pretreatment. MASCA corrected datc $=$ A.D. 1034 .

General Comment (N.C.D.): Pouss is S-most mound of any size on left bank of Logone R. Preliminary typologic analysis suggests that materials represent impoverished S facies of Sac civilization. P-1767 was from lowest horizons of occupation, though burials occur $1 \mathrm{~m}$ below at depth $5.75 \mathrm{~m}$.

\section{Sumpa Cave series}

Sumpa Cave is in Benue Valley, N Camcroon $\left(9^{\circ} 18^{\prime} \mathrm{N}\right.$ Lat, $13^{\circ} 31^{\prime}$ E Long), only known site in area containing Neolithic phase. Samples coll. 1969 by Frank Bartell; subm. by N. C. David.

P.1635. C:2 and $A: 2$

Charcoal, Sample $\mathrm{C}: 2$ and A:2, from strat. Unit 1b. Comment: $\mathrm{NaOH}$ pretreatment. MASCA corrected date $=$ A.D. 1542.

\section{P-1636. C:4}

A.D. 1848

$102 \pm 39$

Charcoal, Sample C:4 from strat. Unit 2b. Comment: MASCA corrected date $=$ A.D. 1794 .

\section{F.1637. C:6 and D:3}

$346 \pm 51$

Charcoal, Samples C:6 and D:3 from strat. Unit 3. Comment: $\mathrm{NaOH}$ pretreatment. MASCA corrected date $=$ A.D. 1543.

\section{P.1638. C:8, C:7, A:5, and A:6}

$$
704 \pm 42
$$

Charcoal, Samples $C: 8, C: 7, A: 5$, and $A: 6$ from strat. Units 4 and 5. Comment: MASCA corrected date = A.D. 1224 .

General Comment (N.C.D.): deposits were extensively disturbed by burrowing animals and cave was used until very recently as a stall for sheep and goats. Dates are valueless. Preliminary typologic analyses suggest that both P-1637 and -I638 should fall within lst 2 millennia B.c.

\section{Douloumi series}

Douloumi is Iron age mound with ca. $4 \mathrm{~m}$ cultural stratigraphy, on Lake Douloumi in N Cameroon ( $9^{\circ} 12^{\prime} \mathrm{N}$ Lat, $13^{\circ} 39^{\prime} \mathrm{E}$ Long). Sample coll. 1969 by Frank Bartell; subm. by N. C. David. 
P-1761. Strat. Units 5, 6, and 7

$1089 \pm 41$

Charcoal, burnt bone, and soil from strat. Units 5, 6, and 7 of Iron age assemblage. Comment: MASCA corrected date $=$ A.D. 878.

\section{P-1763. Strat. Units 17 and 18}

$1074 \pm 47$

Charcoal, soil, and rootlets from strat. Units 17 and 18 of Iron age assemblage. Comment: rootlets removed by hand. $\mathrm{NaOH}$ pretreatment. MASCA corrected date $=$ A.D. 894.

\section{P-1764. Strat. Units 20 and 21}

$1412 \pm 50$

Charcoal, burnt bone, soil, and rootlets from strat. Units 20 and 21 of Iron age assemblage. Comment: rootlets removed by hand. MASCiA corrected date $=$ A.D. 546 .

General Comment (N.C.D.): P-1764 comes from lowest horizons of occupation and represents earliest, but surprisingly late, Iron age occupation so far found in area. P-1761, 1.75m above P-1763 in strat. appears too old. A date in Ist millennium A.D. was expected.

\section{Be series}

Be, an Iron age mound with $7 \mathrm{~m}$ cultural material, unoccupied since A.D. 1839, Fulani conquest of the Nyam-nyam village, is in the Mayo Kebbi Valley, N Cameroon $\left(9^{\circ} 18^{\prime} \mathrm{N}\right.$ Lat, $13^{\circ} 40^{\prime} \mathrm{E}$ Long). Samples coll. 1969 and subm. by N. C. David.

\section{Pit A}

P.1744. Strat. Units 7 and 8

$258 \pm 39$

Charcoal and soil from anbituary strat. Units 7 and 8. Comment: $\mathrm{NaOH}$ pretreatment. MASCA corrected date $=$ A.D. 1634 .

\section{P-1557. Strat. Unit 12}

$410 \pm 36$

Charcoal from arbitrary strat. Unit 12. Comment: MASGA corrected date $=$ A.D. 1458 .

\section{P.1746. Strat. Unit 25}

$832 \pm 49$

Charcoal and soil from arbitrary strat. Unit 25. Comment: $\mathrm{NaOH}$ pretreatment. MASCA corrected clate $=$ A.D. 1093.

\section{P-1747. Strat. Unit 30}

Charcoal and soil from arbitrary strat. Unit 30. Comment: $\mathrm{NaOH}$ pretreatment. Undersized sample $(89 \%)$, therelore not as reliable. MASCA corrected date $=$ A.D. 1427. 
P-1748. Strat. Unit 34

Charcoal and soil from arbitrary strat. Unit 34. Comment: $\mathrm{NaOH}$ pretreatment. MASCA corrected date $=$ A.n. 1021 .

P-1684. Strat. Unit. 38

$$
1106 \pm 33
$$

A.D. 844

Charcoal and soil from arbitrary strat. Unit 38, lowest occupational horizon. Comment: $\mathrm{NaOH}$ pretreatment. MASCA corrected date $=$ A.D. 860.

General Comment (N.C.D.): radiocarbon dates suggest average rate of accumulation of $7 \mathrm{~mm} / \mathrm{yr}$, and with exception of undersized Sample P-1747, may be considered satisfactory.

\section{Be Pit B}

P-1750. Strat. Units 6 to 10

$275 \pm 53$

Charcoal and soil from strat. Unit 6 to 10. Comments: MASCA corrected date $=$ A.D. 1616. (N.C.D.): date appears too young, but is made up of 6 sub-samples from zone $>1 \mathrm{~m}$ deep. Expected date: ca. A.1. 1000.

\section{P-1753. Strat. Units 19 to 22}

$1014 \pm 48$

Charcoal with many rootlets from Units 19 to 22. Comments: rootlets removed by hand. MASCA corrected date = A.D. 956. (N.C.D.): sample corresponds well with stratigraphically equivalent P-l684 from Pit $A$.

\section{Alaska}

$$
\text { D. Arctic }
$$

\section{Unalakleet series}

Unalakleet Old Village consists of 200 to 300 house pits on older beach ridge now ca. $4 \mathrm{~km}$ from coastline of Norton Sound, Alaska $\left(64^{\circ}\right.$ N Lat, 161 ${ }^{\circ}$ E Long). Samples coll. 1968, 1969 and subm. 1969 by Bruce Lutz, Univ. Mus., Univ. Pennsylvania, Philadelphia, Pennsylvania (1969).

\section{P-1530. Ipiutak house}

$1556 \pm 48$

Charcoal from within floor of Ipiutak house, coll. 1968. Comment: MASCA corrected date $=$ A.D. 297.

\section{P-1772. Ipiutak house}

$1810 \pm 40$

Charcoal from $W$ hearth of Ipiutak house (house had 2 hearths), coll. 1969. Comment: $\mathrm{NaOH}$ pretreatment. P-1530 was obtained near hearth. MASCA corrected date $=$ A.D. 135.

\section{P-1531. House 2}

$1976 \pm 50$

Charcoal from hearth on floor of House 2, coll. 1968. Comment: on typologic grounds (i.e., presence of burins), should be earlier than Cape 
Denbigh Norton, P-13, $2213 \pm 110$ (R., 1961, v. 3, p. 11). MASCA corrected date $=86$ в.c.

\section{P.1532. House 3}

$2091 \pm 50$

Charcoal from hearth at bottom of floor midden of House 3. Comment: same as for P-1531. MASCA corrected date $=204$ в.c.

\section{P.1771. House 120}

$2140 \pm 47$

Charcoal from hearth on floor of House 120. Comment: rootlet pretreatment (Haynes, 1966; Lowdon et al., 1970). MASCA corrected date $=304$ в.с.

\section{GEOLOGIC SAMPLES}

\section{United States}

\section{A. North America}

\section{Island Field, Delaware series}

Spartina alterniflora marsh peat or plant fragments embedded in marsh mud at Island Field Archaeol. Site, S Bowers, Delaware $\left(39^{\circ} 3^{\prime}\right.$ $\mathrm{N}$ Lat, $75^{\circ} 23^{\prime} \mathrm{W}$ Long). Samples are from different peat horizons within a marshy sequence, building upwards and advancing landward for the past 3 to 5000 yr. Coll. 1968, 1969 by J. C. Kraft, Univ. Delaware, Newark, Delaware; subm. by R. A. Thomas.

\section{P.1687. JCK DH 1-68}

JCK DH 1-68, $2.13 \mathrm{~m}$ to $2.64 \mathrm{~m}$. Comment: $\mathrm{NaOH}$ pretreatment.. MASCiA corrected date $=61$ в.c.

\section{P-1686. JCK DH-1-69}

$1950 \pm 55$

JCK DH 1-69, Core $1,4.57 \mathrm{~m}$ to $4.88 \mathrm{~m}$. Comment: $\mathrm{NaOH}$ pretreatment. MASCiA corrected date $=59$ в.c.

\section{P-1688. JCK DH-1-69}

$2999 \pm 59$

JCK DH 1-69, Core $3,6.10 \mathrm{~m}$ to $6.40 \mathrm{~m}$. Comment: NaOH pretreatment. MASCA corrected date $=1289$ в.c.

P-1685. JCK, DH 5-69

$3314 \pm 63$

CK, 1015 J6, $6.60 \mathrm{~m}$ to $6.86 \mathrm{~m}$. Comment: NaOH pretreatment. MASGA corrected clate $=1664$ is.c.

\section{P.1669. JCK Core 11}

JCK Core 11, Part 2-69, 2.24m to 2.57m. Comment: $\mathrm{NaOH}$ pretreatment. MASCA corrected date $=298$ в.c. 


\section{Corrections}

R., 1969, v. 11, p. 152: P-1434 should be $4285 \pm 62$ (2335 13.C.), pub-

lished correctly in R., 1971, v. 13, p. 371, but not designated as a correction.

R.. 1971, v. 13, p. 365; P-1392 should be P-1394.

RFFFREXCFS

Braidwood, R. J. and Braidwood, L. S., 1960, Fxcatuations in the Plain of Antioch, I: Oriental Inst. Pubs., v. 61, p. 259-262.

Braidwood, R. J., Cambel, Halet, Redman, C. L., and Watson, P. J., 1971, Beginnings of village-farming communities in southeastern Turkey: Natl. Acad. Sci. Proc., v. 68 , no. 6, p. I236-1240.

Braidwood, R. J. and Howe, Bruce, 1960, Prehistoric investigations in Iraqi Kurdistan: Chicago, Univ. Chicago Press, p. 1-184.

Brown, F. E., 1951, Cosa I, history and typography: Am. Acad. in Rome Mem., v. 20 , p. 89.

Buckley, J. D. and Willis, E. H., 1970, Isotopes' radiocarbon measurcments VIII: Radiocarbon, v. 12, p. 87-129.

Damon, P. E., Long, Austin, and Grey, D. C., 1970, Arizona radiocarbon dates for dendrochronologically dated samples, in: Olsson, I. U., (ed.) 12th Nobel symposium Proc., Uppsala, Sweden, Aug. 11-15, 1969, Radiocarbon variations and absolute chronology: Stockholm, Almquist and Wiksell (New York, John Wiley and Sons), p. 615-618.

Delougaz, Pinhaz and Lloyd, Seton, 1942, Pre-Sargonid temples in the Divala region: Chicago, Univ. Chicago Press, 320 p.

Dyson, Robert, Jr., 1965, Problems of protohistoric Iran as seen from Hasanlu: Near Eastern Studics Jour., v. 24, p. 193-217.

Iiaynes, C. V., Jr., 1966, Radiocarbon samples: chemical removal of plant contaminants: Science, v. 151, p. 1391-1392.

Lawn, Barbara, 1970, Univ. of Pennsylvania radiocarbon dates XIII: Radiocarbon, v. 12 , p. $577-589$.

Lloyd, Seton and Safar, raud, 1943, Tell Uqair, excavations by the Iraq Government Directorate General of $\Lambda$ ntiquities in 1940 and 1941: Near Eastern Studies Jour., v. 2, no. 2, p. 131-158.

Lowdon, J. A., Wilmeth, R., and Blake, W., Jr., 1970, Geological Survey of Canada radiocarbon dates $X$ : Radiocarbon, v. 12, p. 472-485.

Lutz, Bruce, 1969, Archacological investigations near Unalakleet, Alaska: Expedition, v. 11, no. 2, p. $52-54$

Mallowan, M. E. L., 1936, Excavations at Tell Chagar Bazar: Iraq, v. 3, p. 1-86.

Matson, F. R., 1960, Specialized ceramic studies and radioactive-carbon techniques, in: Braidwood, R. J. and Howe, Bruce, op. cit., above, p. 184.

Münnich, K. O., 1957, Heidelberg natural radiocarlion measurements I: Science, v. 126, p. 194-199.

Ralph, E, K., 1959, Lniv. of Pemsyivania rasliocabon dates III: Radiocarbon, v. 1, p. $45-58$

1971, Carbon-14 dating, in: Michael, H. N. and Ralph, E. K., (cds.), Dating techniques for the archacologist: Cambridge, Mass., The MII Press, p. 1-48.

Ralph, E. K. and $\Lambda$ ckerman, R. l., 1961, Univ. of Pennsylvania radiocarbon dates IV: Radiocarbon, v. 3, p. 4-14.

Ralph, E. K. and Michacl, H. N., 1970, MASCA radiocarbon dates for sequoia and bristlecone-pine samples, in: Olsson, I. U., (ed.), op. cit., above, p. 619-623.

Rubin, Mcyer and Alcxander, Corrinne, 1960, U.S. Gcological Survey radiocarbon dates V: Radiocarbon, v. 2, p. 129-185

Sato, Jun, Sato, Tomoko, Otomori, Yasuko, and Suzuki, Hisashi, 1969, University of Tokyo radiocarbon measurements II: Radiocarbon, v. Il, p. 509-514.

Starr, R. I. S., 1939, Nuzi, I., II: Cambridge, Harvard Univ. Press, 615 p. and pls.

Stuckenrath, Robert, Jr., 1963, University of Pennsylvania radiocarbon dates VI: Radiocarbon, v. 5, p. 82-103. 
Stuckenrath, Robert, Jr., Coe, W. R., and Ralph, E. K., 1966, University of Pennsylvania radiocarbon dates $I X$ : Radiocarbon, v. 8, p. 348-385.

Stuckenrath, Robert, Jr. and Ralph, E. K., 1965, University of Pennsylvania radiocarbon dates VIII: Radiocarbon, v. 7, p. 187-199.

Suess, H. E., 1970, Bristlecone-pine calibration of the radiocarbon time-scale 5200 в.c. to the present, in: Olsson, I. U. (ed.), op. cit., above, p. 303-311.

Tauber, Henrik, 1968, Copenhagen radiocarbon dates IX: Radiocarbon, v. 10, p. $295-327$.

Tobler, A. J., 1950, Excavations at Tepe Gawra, V. II: Philadelphia, Univ. Pennsylvania Press, $262 \mathrm{p}$.

Vogel, J. C. and Waterbolk, H. T., 1964, Groningen radiocarbon dates V: Radiocarbon, v. 6, p. 349-369.

Watson, P. J., 1965, The chronology of north Syria and north Mesopotamia from 10,000 B.c. to 2000 B.c., in: Ehrich, R. W., (ed.), Chronologies in old world archacology: Chicago, Univ. Chicago Press, p. 61-100. 